\title{
The first plesiosaurian (Sauropterygia, Pliosauridae) remains described from the Jurassic of Poland
}

\author{
Dean R. Lomax
}

\begin{abstract}
Plesiosaur remains are rare in Poland. The first confidently documented occurrence of the group from the Jurassic of Poland is reported. The specimens comprise three isolated teeth of a pliosaurid (Pliosauridae, Thalassophonea). These were found in Upper Jurassic (lower Oxfordian) sediments and were collected from Zalas Quarry, near Kraków, in southern Poland. Fossils from the vicinity of the Zalas area have been collected since the 1800 s, yet no report of vertebrate remains has previously been described.
\end{abstract}

Dean R. Lomax. School of Earth, Atmospheric and Environmental Sciences, The University of Manchester, Oxford Rd, Manchester, M13 9PL, UK. dean.lomax@manchester.ac.uk and Doncaster Museum \& Art Gallery, Chequer Rd, Doncaster, DN1 2AE, UK

Keywords: Poland; pliosaurid; Plesiosauria; marine reptile; Upper Jurassic; Oxfordian

\section{INTRODUCTION}

Plesiosaurs are an unusual group of extinct marine reptiles. They have been discovered on all continents and are represented by complete to fragmentary specimens recorded from sediments of the uppermost Triassic (Rhaetian) to the upper Cretaceous (Storrs and Taylor, 1996; Cruickshank and Fordyce, 2002). Their remains are plentiful in Europe, especially in Jurassic-aged deposits, with major discoveries recorded from the UK, Germany and Svalbard (e.g., Grossman, 2007; Vincent and Smith, 2009; Smith and Vincent, 2010; Druckenmiller and Knutsen, 2012; Knutsen, 2012; Benson et al., 2013). However, plesiosaurs are poorly represented in Poland with only a few fragments recorded. A single purported plesiosaur tooth along with some isolated fish remains were reported from the Middle Bathonian of the Polish Jura by Rehbinder (1913), although the remains were not described or illustrated. However, the fish remains were later identified as that of an actinopterygian fish (Smith and Zatoń, 2007). The supposed plesiosaurian tooth cannot currently be located, and verification of the tooth as plesiosaurian is not possible. Additional plesiosaur fragments have been collected from Cretaceous sediments (see discussion in Bardet and Godefroit, 1995, p. 183; Bardet et al., 2015).

Despite the severe lack of Jurassic and Cretaceous marine reptile specimens in Poland several important reptilian remains have been collected

PE Article Number: 18.2.29A

Copyright: Palaeontological Association June 2015

Submission: 4 November 2014. Acceptance: 25 May 2015

Lomax, Dean R. 2015. The first plesiosaurian (Sauropterygia, Pliosauridae) remains described from the Jurassic of Poland.

Palaeontologia Electronica 18.2.29A: 1-8

palaeo-electronica.org/content/2015/1230-jurassic-pliosaurid-poland 
from Triassic exposures. Some key discoveries include dinosaurs (Niedźwiedzki et al., 2014), kuehneosaurids (Evans, 2009), nothosaurs (Rieppel, 2000), the rare occurrence of ichthyosaurs (McGowan and Motani, 2003) and rauisuchian reptiles (Brusatte, et al., 2009) and their traces (Niedźwiedzki et al., 2013).

Reported here are three isolated plesiosaur teeth collected in 1997 at Zalas Quarry, Kraków. The teeth remained unstudied although they are featured in a local booklet regarding the geology of Zalas in which they were mistakenly identified as the teeth of ichthyosaurs (Molenda, 1997). Their tooth morphology suggests they belong to a pliosaurid (Pliosauroidea, Pliosauridae, Thalassophonea). Measurements were taken using digital callipers and were recorded to the nearest $0.1 \mathrm{~mm}$.

\section{Institutional Abbreviations}

GM: Faculty of geology, geophysics and environmental protection, Geological Museum, Kraków.

\section{GEOLOGICAL SETTING}

Zalas Quarry is a large, active quarry situated in the eastern part of the village of Zalas, near to the town of Krzeszowice, about $30 \mathrm{~km}$ west of the city of Kraków in southern Poland, located in the southern part of the Polish Jura Chain (Figure 1). With numerous fossils described, it is a well-known Jurassic locality that has been explored and studied since the 1870s (Matyja and Tarkowski, 1981; Borszcz and Zatoń, 2009). Access to the site is only possible with permission. New exposures of the Jurassic strata of the area allowed for further examination and detailed descriptions of newly collected remains. The exposed Jurassic strata in the Zalas area comprise rocks of the uppermost Callovian and lower and middle Oxfordian. The biostratigraphy of the Zalas Quarry has been well recorded. For an overview and further detailed description of the geology of the area please refer to Matyja and Tarkowski (1981) and Jurkowska and Kolodziej (2012); a general overview is given by Molenda (1997) and Borszcz and Zatoń (2009).

A wealth of invertebrate fossil remains has been described from the Zalas area, many of which have represented new genera and species. This fossil fauna includes brachiopods, bivalves, nautiloids, ammonites, gastropods, belemnites, corals, bryozoans, serpulids, sponges, echinoids, crinoids, brittle stars, stromatolites, polychaetes, crabs and radiolarians (Gizejewska and Wieczorek, 1976; Matyja and Tarkowski, 1981; Trammer, 1989; Molenda, 1997; Górka and Bak, 2000; Borszcz and

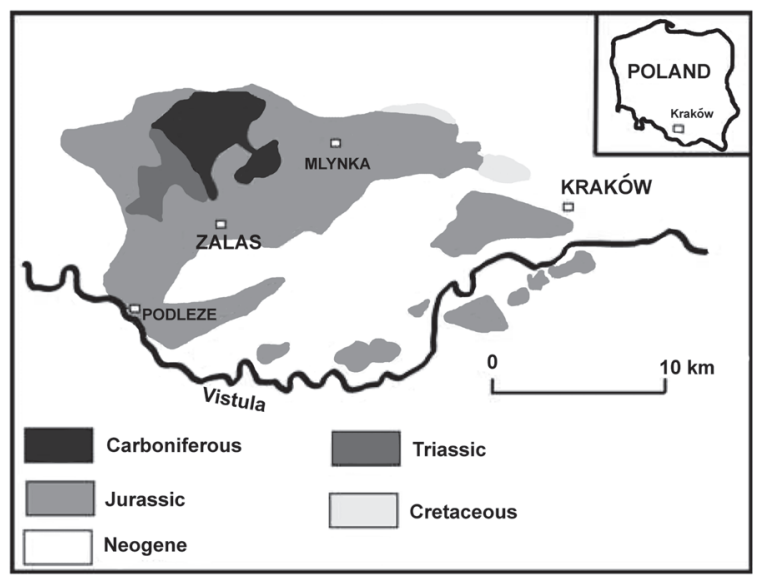

FIGURE 1. Geographical location and geological exposures of the area around Zalas, southern Poland. Modified slightly from Jurkowska and Kolodziej (2012, figure 1).

Zatoń, 2009; Jurkowska and Kolodziej, 2012; Zatoń et al., 2013). In contrast, there is a severe lack of vertebrate remains. As well as the isolated plesiosaur teeth reported in this study, shark teeth have been collected but are rare and have also remained unstudied (personal obs.). Borszcz and Zatoń (2009, p. 5) briefly mentioned the exceptionally rare occurrence of shark and 'marine reptile' teeth; the latter presumably referring to the studied specimens. To the author's knowledge, no detailed report of vertebrate remains from the Jurassic of the Zalas area has been undertaken.

The studied plesiosaur teeth were found in a single block of marly limestone. They were collected from a rare horizon whereby a mixture of pink, yellow and grey coloured marl is present, corresponding to the level of the Quenstedtoceras mariae ammonite Zone, the lowermost Oxfordian (Matyja and Tarkowski, 1981; Molenda, 1997).

\section{SYSTEMATIC PALAEONTOLOGY}

\author{
Superorder SAUROPTERYGIA Owen, 1860 \\ Order PLESIOSAURIA de Blainville, 1835 \\ Superfamily PLIOSAUROIDEA Welles, 1943 \\ Family PLIOSAURIDAE Seeley, 1874 \\ Clade THALASSOPHONEA Benson and \\ Druckenmiller, 2013 \\ THALASSOPHONEA GEN. ET SP. INDET. \\ Figures 2-4
}

\section{Description}

GM001. This specimen is the best of the three examples preserved (Figure 2). The tooth comprises a single, complete crown missing the root; it 


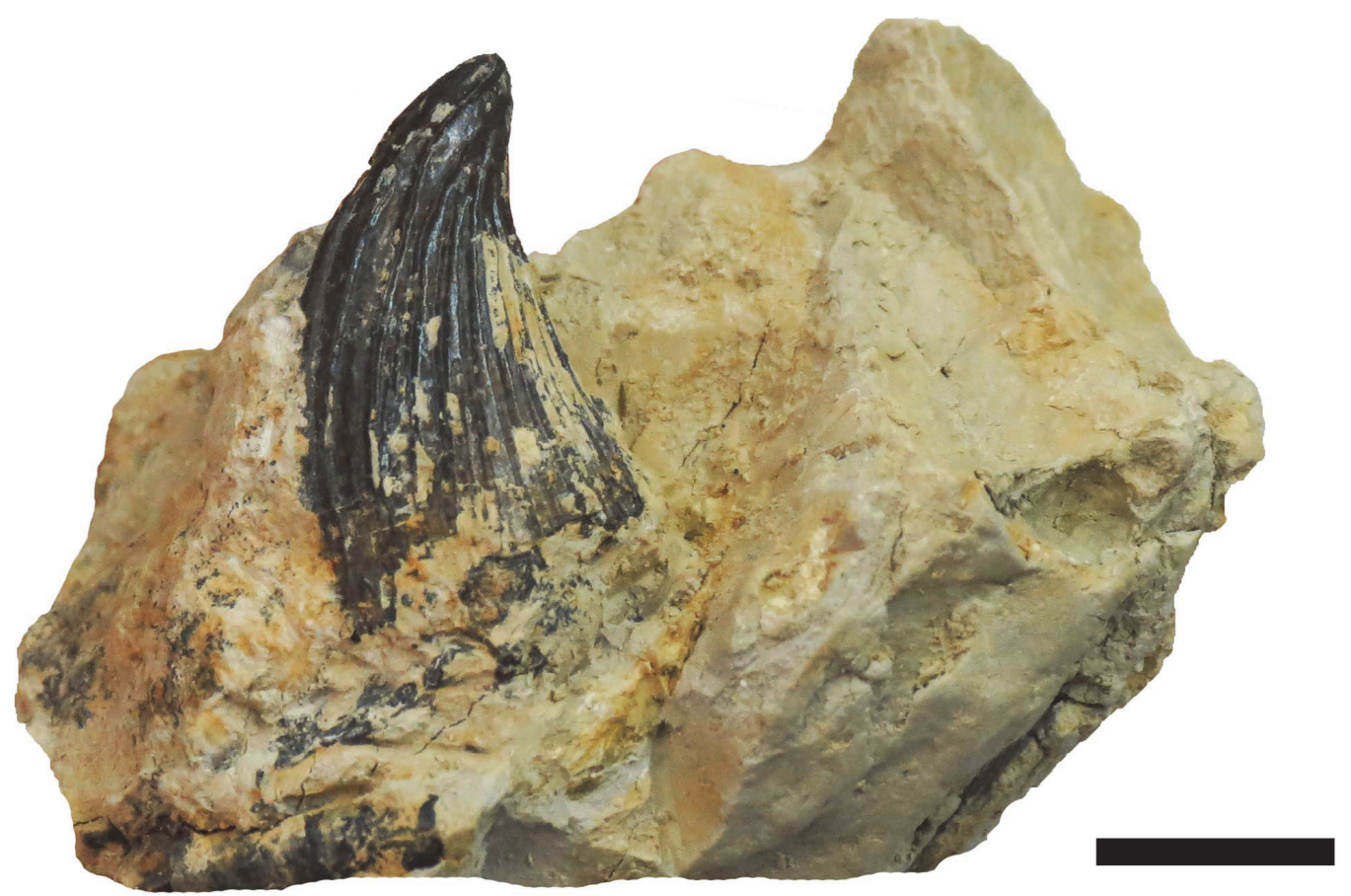

FIGURE 2. Mesial view of the tooth crown of GM001. Note the coarse longitudinal ridges and recurved apex. Scale bar measures $10 \mathrm{~mm}$.

is black in colouration. The crown is conical, robust and displays coarse longitudinal ridges that extend to the tip. The longitudinal ridges are evenly spaced throughout, present on the labial, lingual, mesial and distal surfaces of the crown. The pointed apex of the tooth crown is lingually curved (recurved). The crown has a maximum height of $23.2 \mathrm{~mm}$, it measures $12.8 \mathrm{~mm}$ at its widest point at the base and the tip measures $2.6 \mathrm{~mm}$ wide.

GM002. This specimen comprises an almost complete tooth including the entire root and crown, although the tip is missing (Figure 3). The crown is black and the root is greyish-brown in colouration. The crown is conical, robust, lingually curved (recurved) and displays coarse longitudinal ridges throughout. In comparison to the crown, the root is smooth and results with a strong delineation between the crown and root. The longitudinal ridges are evenly spaced throughout, present on the labial, lingual, mesial and distal surfaces of the crown. The total length of the tooth measured from the base of the crown to the apical-most portion is $52.5 \mathrm{~mm}$. The crown height measures $17.3 \mathrm{~mm}$, its widest point measures $11.4 \mathrm{~mm}$ and the most proximal portion measures $6.7 \mathrm{~mm}$. The widest point of the root measures $12.1 \mathrm{~mm}$. Fragments of a belemnite and ammonite are preserved alongside the tooth.
GM003. This is the least well preserved of the studied specimens (Figure 4). Only a portion of the crown is present and the tip and root are missing. It is light brown in colouration. The crown has longitudinal ridges although the (?)labial surface is damaged with much of the enamel missing, which results in a 'smooth' appearance. The preserved crown has a maximum height of $16.9 \mathrm{~mm}$, its widest point measures $12.7 \mathrm{~mm}$ and the most apical portion towards the tip measures $7.9 \mathrm{~mm}$. A fragment of an ammonite is preserved adjacent to the tooth.

\section{Remarks}

All of the specimens were collected together in a single block. Based on the close association, it is probable that the studied specimens belong to the same individual. However, GM003 has a slightly different morphology (although this could be due to preservation) and colouration, which may suggest that it is from another position in the jaw or perhaps another individual (Taylor and Cruickshank, 1993). Arguably, each specimen could have benefited from additional preparation, but this was not possible and it does not detract from their individual description. Aside from the specimens above, a fragment of poorly preserved and worn bone (GM004) was also collected but this single 


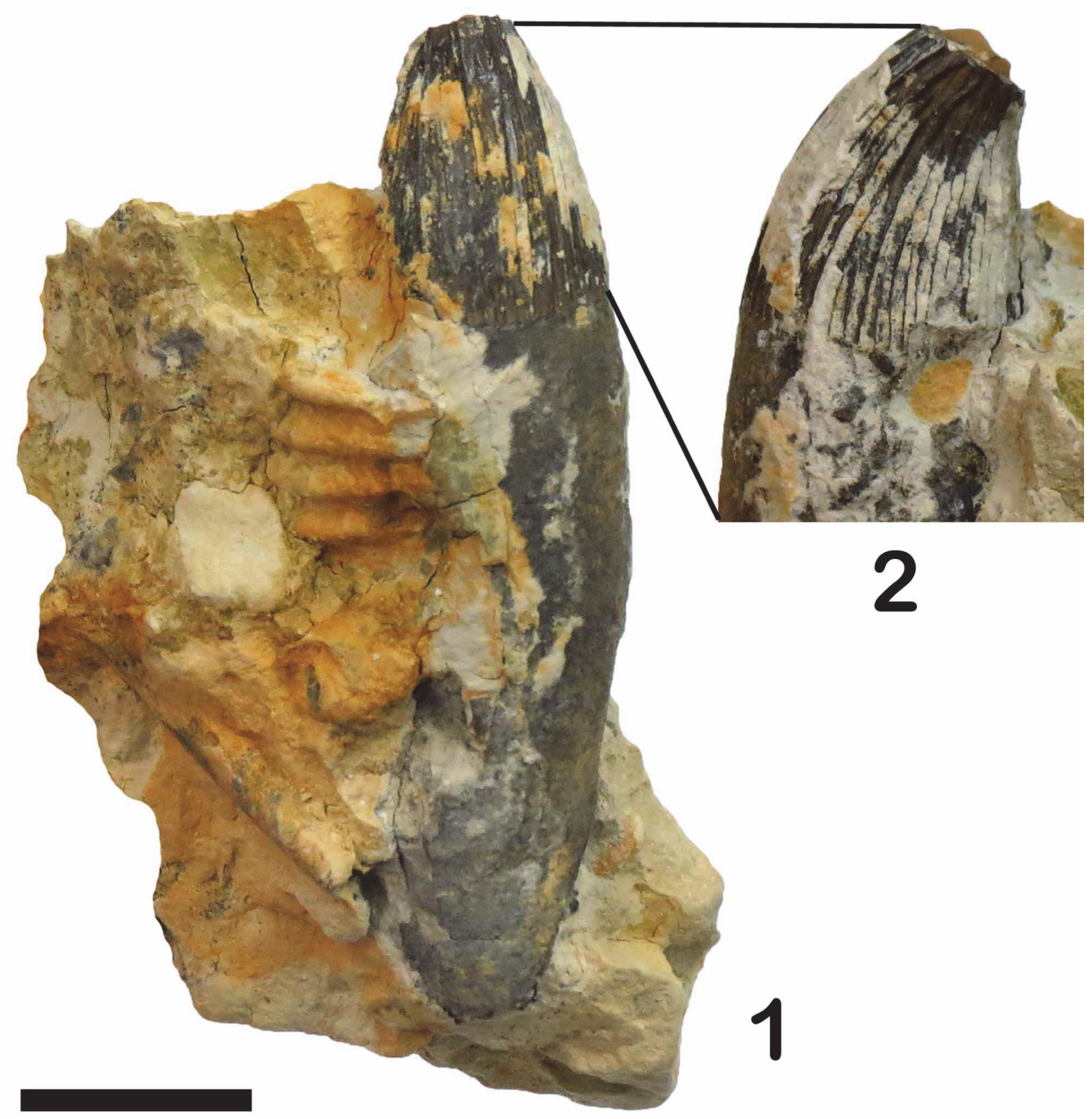

FIGURE 3. 1. Lingual view of the entire tooth of GM002. 2. Enlarged close-up of tooth crown in mesial view. Scale bar measures $10 \mathrm{~mm}$.

fragment could not be identified beyond Reptilia Indet and is not discussed further. Additionally, another indeterminate bone fragment of perhaps a worn vertebral centrum was collected in 1994 (figured in Molenda, 1997) but this is held in a private collection and was not examined by the author.

\section{DISCUSSION}

Tooth morphology varies in Mesozoic marine reptiles (Massare, 1987). Ichthyosaur tooth shape can vary from slender and sharply pointed to large and robust, although most have the form of slightly curved, simple cones. The crown apex is usually smooth but the remainder of the crown can be longitudinally striated or smooth, and some species have flattened crowns with an anterior and posterior carinae (Massare, 1987; McGowan and Motani, 2003). The teeth of marine crocodylomorphs range from stout and robust to fairly slender, laterally compressed cones. The crowns can be smooth or display fine longitudinal ridges, and most have anterior and posterior carinae 


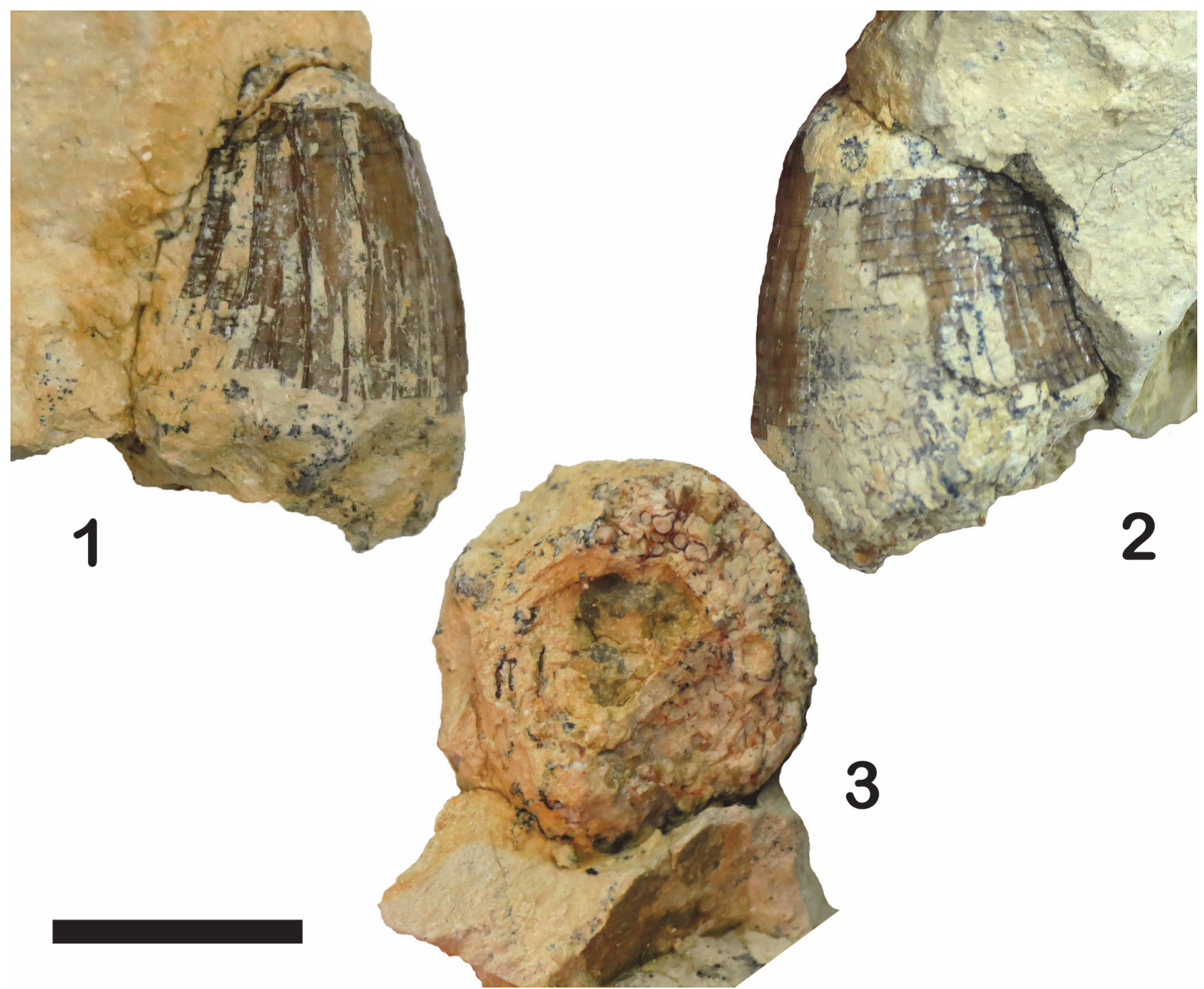

FIGURE 4. 1. ?Lingual view of the tooth crown of GM003. 2. ?Labial view of tooth crown with missing enamel and less prominent ridges. 3. Underside of tooth displaying circular cross section. Scale bar measures $10 \mathrm{~mm}$.

(Andrews, 1913; Massare, 1987; Grange and Benton, 1996; Young et al., 2010, 2013). Tooth shape in 'plesiosauromorphs' varies from long, lingually curved cones with pointed apices to long, robust and pointed apices. Crowns can be smooth or subtly striated (Andrews, 1913; Massare, 1987; Martill, 1991).

The studied teeth are stout and conical in shape. The crown is strongly recurved with longitudinal ridges that reach the apex. This tooth form differs from those discussed above and is most similar to the morphologies of several Middle and Late Jurassic pliosaurids (Andrews, 1913; Tarlo, 1960; Massare, 1987, p. 126-127; Martill, 1991, figure 10.3; Taylor and Cruickshank, 1993, figure 11; Benson et al., 2013, figure 21). The broad-based conical shape of the teeth is indicative of a posterior position in the tooth row (Taylor and Cruickshank, 1993). Their general morphology, along with the presence of the widely spaced longitudinal ridges, suggests that they may be referred to the Pliosauridae (Seeley, 1874; Andrews, 1913; Knutsen, 2012, figure 3; Benson et al., 2013, figure 21). One comparative example of the Pliosauridae is the Late Jurassic Pliosaurus. Since its description in 1841, Pliosaurus became a wastebasket taxon with the referral of numerous isolated bones and skeletons to the genus (Knutsen, 2012). There are at least six, and as many as eight, currently valid species of Pliosaurus (Benson et al., 2013, p. 4). There are seven autapomorphies for Pliosaurus and one includes trihedral or subtrihedral teeth (Benson et al., 2013). The cross section of the teeth in the studied specimens appears circular. The base is broken in specimen GM003 which allows for a closer examination of a circular cross section (Figure 4.3). This shape rules out referral of the teeth to Pliosaurus. However, one questionable 
species of the genus, $P$. andrewsi has teeth that are circular in cross section (Knutsen, 2012). This species has been suggested to possibly represent a new taxon but requires further revision (Knutsen, 2012; Benson et al., 2013). Other Jurassic pliosaurids from the slightly older Callovian (Middle Jurassic) such as Pachycostasaurus (Cruickshank et al., 1996) and Lioplerurodon (Andrews, 1913; Tarlo, 1960) have teeth similar to the studied specimens and are round in cross section. It is thus possible that the studied specimens are perhaps related to those genera.

Although differences in pliosaurid tooth morphology have been used taxonomically (e.g., Tarlo, 1960; Knutsen, 2012; Benson, et al., 2013), tooth morphology alone is not always enough for confident identification to genus or species level. This is further exemplified by comparison of pliosaurid teeth from the Cretaceous. Similar tooth shape (conical, recurved and longitudinally ridged crowns) as the studied specimens has been found in Cretaceous pliosaurid taxa (Welles and Slaughter, 1963; Carpenter, 1996). This further suggests that more complete remains may enable the confident referral of such isolated specimens to genus or species level. For this reason the studied specimens are indeterminate at genus level but are identified as belonging to the Pliosauridae and further identified as a basal member of the clade Thalassophonea (Benson and Druckenmiller, 2013).

Plesiosaur remains from Poland are rare. Described here are the first remains of plesiosaurs (Pliosauridae, Thalassophonea) from the Jurassic of Poland, which despite their fragmentary nature add to our understanding of the ecology of the Zalas Quarry and the distribution of plesiosaur remains in Poland. It is hoped that continued collecting at the Zalas Quarry will yield more complete remains of plesiosaurs and other marine reptiles.

\section{ACKNOWLEDGEMENTS}

I wish to thank A. Borek and R. Borek for arranging a field trip in 2014 to the Zalas Quarry, and subsequently bringing to my attention the studied specimens. Additionally, many thanks to A. Borek for translating text and spoken language. This significantly helped to progress the manuscript and my research. Thanks to R. Molenda of the GM for allowing examination of the teeth and for discussing their discovery. Thanks also to J. Massare and A. Smith for discussing the identification of the studied teeth and clarifying some of my comments. Finally, thanks to two anonymous reviewers for helpful comments and suggestions in order to progress this manuscript.

\section{REFERENCES}

Andrews, C.W. 1913. A Descriptive Catalogue of the Marine Reptiles of the Oxford Clay, Part II. British Museum (Natural History), London.

Bardet, N. and Godefroit, P. 1995. Plesiosaurus houzeaui Dollo, 1909 from the Upper Campanian of Ciply (Belgium) and a review of the Upper Cretaceous plesiosaurs from Europe. Bulletin de l'Institut Royal des Sciences Naturelles de Belgique, Sciences de la terre, 65:179-186.

Bardet, N., Fischer, V., and Machalski, M. 2015. Large predatory marine reptiles from the Albian-Cenomanian of Annopol, Poland. Geological Magazine, doi:10.1017/S0016756815000254

Benson, R.B.J. and Druckenmiller, P.S. 2013. Faunal turnover of marine tetrapods during the JurassicCretaceous transition. Biological Reviews, 89:1-23.

Benson, R.B.J., Evans, M., Smith, A.S., Sassoon, J., Moore-Faye, S., Ketchum, H.F., and Forrest, R. 2013. A giant pliosaurid skull from the Late Jurassic of England. PLoS ONE 8(5): e65989. doi:10.1371/ journal.pone.0065989.

de Blainville, H.D. 1835. Description de quelques espéces de reptiles de la Californie, précéde' de l'analyse d'un systéme général d'Erpétologie et d'Amphibiologie. Nouvelles Annales du Museum National d'Histoire Naturelle, 4:233-296.

Borszcz, T. and Zatoń, M. 2009. Exploring the Jurassic at Zalas Quarry, southern Poland. Deposits Magazine, 20:4-7.

Brusatte, S.L., Butler, R.J., Sulej, T., and Niedźwiedzki, G. 2009. The taxonomy and anatomy of rauisuchian archosaurs from the Late Triassic of Germany and Poland. Acta Palaeontologica Polonica, 54:221-230.

Carpenter, K. 1996. A review of short-necked plesiosaurs from the Cretaceous of the Western Interior, North America. Neues Jahrbuch für Geologie and Paláontologie, 20:259-287.

Cruickshank, A.R.I., Martill, D.M., and Noè, L.F. 1996. A pliosaur (Reptilia, Sauropterygia) exhibiting pachyostosis from the Middle Jurassic of England. Journal of the Geological Society, 153:873-879.

Cruickshank, A.R.I. and Fordyce, R.E. 2002. A new marine reptile (Sauropterygia) from New Zealand: further evidence for a Late Cretaceous austral radiation of cryptoclidid plesiosaurs. Palaeontology, 45:557-575.

de Blainville, H.D. 1835. Description de quelques espéces de reptiles de la Californie, précéde' de l'analyse d'un systéme général d'Erpétologie et d'Amphibiologie. Nouvelles Annales du Museum National d'Histoire Naturelle, 4:233-296.

Druckenmiller, P.S. and Knutsen, E.M. 2012. Phylogenetic relationships of Upper Jurassic (Middle Volgian) plesiosaurians (Reptilia: Sauropterygia) from the 
Agardhfjellet Formation of central Spitsbergen, Norway. Norwegian Journal of Geology, 92:277-284.

Evans, S.E. 2009. An early kuehneosaurid reptile (Reptilia: Diapsida) from the Early Triassic of Poland. Palaeontologia Polonica, 65:145-178.

Gizejewska, M. and Wieczorek, J. 1976. Remarks on the Callovian and lower Oxfordian of the Zalas area Kraków upland southern Poland. Bulletin de l'Academie Polonaise des Sciences Serie des Sciences de la Terre, 24:167-176.

Górka, H. and Bak, M. 2000. Early Oxfordian Radiolaria from Zalas Quarry, Kraków Upland, South Poland. Annales Societatis Geologorum Poloniae, 70:165179.

Grange, D.B. and Benton, M.J. 1996. Kimmeridgian metriorhynchid crocodiles from England. Palaeontology, 39:497-514.

Grossman, F. 2007. The taxonomic and phylogenetic position of the Plesiosauroidea from the Lower Jurassic Posidonia Shale of south-west Germany. Palaeontology, 50:545-564.

Jurkowska, A. and Kolodziej, B. 2012. Taphonomic differentiation of Oxfordian ammonites from the Cracow Upland, Poland. Paläontologische Zeitschrift, 87:6782.

Knutsen, E.M. 2012. A taxonomic revision of the genus Pliosaurus (Owen, 1841a) Owen, 1841b. Norwegian Journal of Geology, 92:259-276.

Martill, D.M. 1991. Marine reptiles, p. 226-243. In Martill, D.M. and Hudson, J.D. (eds.), Fossils of the Oxford Clay. The Palaeontological Association, London.

Massare, J.A. 1987. Tooth morphology and prey preference of Mesozoic marine reptiles. Journal of Vertebrate Paleontology, 7:121-137.

Matyja, B.A. and Tarkowski, R. 1981. Lower and Middle Oxfordian ammonite biostratigraphy at Zalas in the Cracow Upland. Acta Geologica Polonica, 31:1-14.

McGowan, C. and Motani, R. 2003. Handbook of Paleoherpetology, Part 8 Ichthyopterygia. Verlag Dr. Friedrich Pfeil, Munich.

Molenda, R. 1997. Zalas, Bear Mountain - History of Mining, Geology, Ecology. Studio Graficzne Szelerewicz i S-ka, Cracow.

Niedźwiedzki, G., Brusatte, S.L., and Butler, R.J. 2013. Prorotodactylus and Rotodactylus tracks: an ichnological record of dinosauromorphs from the EarlyMiddle Triassic of Poland, p.319-351. In Nesbitt, S.J., Desojo, J.B. and Irmis, R.B. (eds.). Anatomy, Phylogeny and Palaeobiology of Early Archosaurs and their Kin. Geological Society Special Publications, London.

Niedźwiedzki, G., Brusatte, S.L., Sulej, T., and Butler, R.J. 2014. Basal dinosauriform and theropod dinosaurs from the mid-late Norian (Late Triassic) of Poland: implications for Triassic dinosaur evolution and distribution. Palaeontology, 57:1121-1142.

Owen, R. 1860. On the orders of fossil and recent Reptilia, and their distribution through time. Report of the
British Association for the Advancement of Science, 1859:153-166.

Rehbinder, B. 1913. Die mitteljurassischen eisenerzführenden Tone längs dem südwestlichen Rande des Krakau-Wieluner Zuges in Polen. Zeitschrift der Deutschen Geologischen Gesellschaft, 63:181-349.

Rieppel, O. 2000. Sauropterygia I. Encyclopedia of Paleoherpethology. München: Verlag Dr. Friedrich Pfeil, Munich.

Seeley, H.G. 1874. Note on some of the generic modifications of the plesiosaurian pectoral arch. Quarterly Journal of the Geological Society of London, 30:436449.

Smith, A.S. and Vincent. P. 2010. A new genus of pliosaur (Reptilia: Sauropterygia) from the Lower Jurassic of Holzmaden, Germany. Palaeontology, 53:1049-1063.

Smith, A.S. and Zatoń, M. 2007. The first Actinopterigian (Pisces: Osteichthyes) tooth from the Bathonian (Middle Jurassic) of the Polish Jura (south-central Poland). Paläontologie, Stratigraphie, Fazies, 524:35-40.

Storrs, G.W. and Taylor, M.A. 1996. Cranial anatomy of a new plesiosaur genus from the lowermost Lias (Rhaetian/Hettangian) of Street, Somerset, England. Journal of Vertebrate Paleontology, 16:404-420.

Tarlo, L.B. 1960. A review of Upper Jurassic Pliosaurs. Bulletin of the British Museum (Natural History), Geology, 4:145-189.

Taylor, M.A. and Cruickshank, A.R.I. 1993. Cranial anatomy and functional morphology of Pliosaurus brachyspondylus (Reptilia: Plesiosauria) from the Upper Jurassic of Westbury, Wilstshire. Philosophical Transactions of the Royal Society B, 341:399-418.

Trammer, J. 1989. Middle to Upper Oxfordian sponges of the Polish Jura. Acta Geologica Polonica, 39:49-91.

Vincent, P. and Smith, A.S. 2009. A redescription of Plesiosaurus propinquus Tate \& Blake, 1876 (Reptilia, Plesiosauria), from the Lower Jurassic (Toarcian) of Yorkshire, England. Proceedings of the Yorkshire Geological Society, 57:133-142.

Welles, S.P. 1943. Elasmosaurid plesiosaurs with description of new material from California and Colorado. Memoirs of the University of California, 13:125254.

Welles, S.P. and Slaughter, B.H. 1963. The first record of the plesiosaurian genus Polyptychodon (Pliosauridae) from the new world. Journal of Paleontology, 37:131-133.

Young, M.T., Brusatte, S.L., Ruta, M., and de Andrade, M.B. 2010. The evolution of Metriorhynchoidea (Mesoeucrocodylia, Thalattosuchia): an integrated approach using geometric morphometrics, analysis of disparity, and biomechanics. Zoological Journal of the Linnean Society, 158:801-859.

Young, M.T., de Andrade, M.B., Brusatte, S.L., Sakamoto, M., and Liston, J. 2013. The oldest known metriorhynchid super-predator: a new genus and species from the Middle Jurassic of England, with 
implications for serration and mandibular evolution in predacious clades. Journal of Systematic Palaeontology, 11:475-513.
Zatoń, M., Hara, U., Taylor, P.D., and Krobicki, M. 2013. Callovian cyclostomes bryozoans from the Zalas Quarry, southern Poland. Bulletin of Geosciences, 88:837-863. 


\section{PE Addendum to: The first plesiosaurian (Sauropterygia, Pliosauridae) remains described from the Jurassic of Poland}

\section{Dean R. Lomax}

Dean R. Lomax. School of Earth, Atmospheric and Environmental Sciences, The University of Manchester, Oxford Rd, Manchester, M13 9PL, UK. dean.Iomax@manchester.ac.uk

Original article: Lomax, D. R. 2015. The first plesiosaurian (Sauropterygia, Pliosauridae) remains described from the Jurassic of Poland. Palaeontologia Electronica 18.2.29A: 1-8 palaeo-electronica.org/content/2015/1230-jurassic-pliosaurid-poland

\section{May 2016}

Whilst studying plesiosaurian remains described and figured in Lomax (2015), the literature was exhaustively searched for descriptions of plesiosaurians from Poland, with a primary focus on Jurassic specimens. Upon assessment of the published record, and information provided from colleagues, it appeared no plesiosaur fossils from the Jurassic of Poland had been previously published. However, it has since been brought to my attention that fragmentary jaws of two plesiosaurs from the Jurassic (Oxfordian) of Załęcze Wielkie on the Warta, and Mirów near Częstochowa, Poland, were described by Maryańska (1972).

\section{REFERENCE}

Maryanska, T. 1972, Aberrant plesiosaurs from the Oxfordian of Poland. Polska Akademia Nauk Muzeum Ziemi Prace Paleozoologiczne, 20, 201206. 